\title{
IM PLEMENTASI STRATEGI HAFALAN AL-QUR'AN TERHADAP HASIL BELAJAR SISWA DI MADRASAH ALIYAH AL-HUDA GORONTALO
}

\author{
Ilham A mpo \\ Pascasarjana IA IN Sultan A mai Gorontalo \\ ilhamfaqier@gmail.com \\ Muh. A rif \\ Pascasarjana IA IN Sultan A mai Gorontalo \\ muharif@iaingorontalo.ac.id
}

\begin{abstract}
A bstract
This article aims to reveal the Implementation of AI-Qur'an Memorization on Student Learning Outcomes at Madrasah Aliyah Al-Huda Kota Gorontalo that following the tahfiz program of learners are always trained to strengthen the reading of the Qur' an knowing the application of good and correct tajwid. The strategy of implementing memorization of the Qur'an for students is to guide students to easily memorize the Qur'an, students who participate in the tahfiz program on average have good ability in reading the Qur'an well and true based on the rules of tajwid, as well as having memorized the verses of the Qur'an which will later become a basic supply to deepen the science of religion. The implication of this research is that tahfiz teachers at M adrasah A liyah A I-Huda Gorontalo City continue to increase their resources in memorizing the Qur'an to support the process of learning activities, especially subjects that cover the Qur'an such as the Qur'an Hadith, Science AI-Qur'an Tajwid and Tahfiz. To all the components in the Madrasah A liyah A I-Huda Kota Gorontalo, namely the foundation, committees, parents and principals, it is hoped to work together for the smooth running of educational programs, especially in the tahfiz A I-Qur' an program.
\end{abstract}

K eywords: Strategies, M emorization of A I-Quran, and L earning Outcomes. 


\section{A bstrak}

Artikel ini bertujuan untuk mengungkapkan Implementasi Hafalan AI-Qur' an terhadap Hasil Belajar Siswa di M adrasah Aliyah Al-Huda Kota Gorontalo bahwasanya mengikuti program tahfiz peserta didik senantiasa terlatih untuk mempermantap bacaan A I-Q ur' an mengetahui penerapan ilmu tajwid yang baik dan benar. Strategi implementasi hafalan A IQur'an bagi peserta didik ialah untuk menuntun siswa agar mudah dalam mengahafal A I-Qur'an, peserta didik yang ikut serta dalam program tahfiz rata-rata memiliki kemampuan yang baik dalam membaca AI-Qur'an yang baik dan benar berdasarkan kaidah tajwid, serta memiliki hafalan ayat-ayat Al-Qur'an yang nantinya menjadi bekal dasar untuk memperdalam ilmu pengetahuan agama. Implikasi penelitian ini adalah guru tahfiz di Madrasah Aliyah Al-Huda Kota Gorontalo terus meningkatkan sumber daya dalam strategi hafalan AI-Qur'an untuk menunjang proses kegiatan pembelajaran khususnya mata pelajaran yang membidangi AlQur' an seperti A I-Qur'an Hadist, IImu Al-Qur' an Tajwid dan Tahfiz. Kepada semua komponen yang ada di Madrasah Aliyah A I-Huda K ota Gorontalo yakni pihak yayasan, komite, orang tua dan kepala sekolah, diharapkan dapat bekerjasama untuk kelancaran program pendidikan terutama pada program tahfiz A I-Qur'an.

Kata K unci: Strategi, Hafalan A I-Qur' an, dan Hasil B elajar.

\section{PENDAHULUAN}

Pembelajaran merupakan proses komunikasi antara guru dan siswa, guru sebagai pendidik sedangkan siswa sebagai objek pendidikan itu sendiri. Jika diamati dari proses pembelajaran tersebut terlihat kegiatan interaksi antara guru dan siswa secara terprogram dalam suatu desain yang terstruktur dan instruksional, hal ini dioperasikan dengan strategi untuk menjadikan siswa belajar secara aktif yang menekankan pada penyediaan sumber belajar. Jika dilihat dari proses pembelajaran sebagaimana yang telah disebutkan bahwa ada tiga aspek penting dari proses pembelajaran tersebut yakni, guru, siswa dan sumber belajar. A pabila salah satu dari ketiga aspek tersebut ada yang kurang, maka proses pembelajaran tidak akan berlangsung, oleh karena itu, pembelajaran dianggap 
sebagai proses yang paling mendasar dalam pendidikan disekolah.

Dalam mengarahkan siswa untuk mencapai tingkat kemampuan yang dimaksud dalam pendidikan, desain pembelajaran disajikan dengan menggunakan strategi yang tepat agar bahan ajar tersebut bisa diterima dan dicerna oleh pemahaman peserta didik. Dalam suatu kondisi ruang belajar yang dihadapi guru, guru akan mendapati sekumpulan siswa yang berbeda-beda dalam setiap kemampuannya masingmasing, untuk itu bahan ajar yang disediakan tidak akan tersalurkan dengan baik tanpa adanya strategi pembelajaran, karena kedudukan strategi sangatlah penting dalam proses pelaksanaan pembelajaran. Dapat dijadikan suatu contoh ketika guru hendak menagajarkan mata pelajaran agama yang materi pemebelajarannya memuat ayat-ayat AI-Qur'an. Bagaimana mungkin pembelajaran tersebut terlaksana dengan baik jika peserta didiknya belum mampu membaca A I-Qur' an, sedangkan dalam pembelajaran agama siswa dituntut untuk bisa membaca ayat Al-Qur'an yang merupakan modal dasar siswa dalam memahami konsep pemebelajaran agama yang nantinya akan diterapkan dalam kehidupan peserta didik sehari-hari.

Didalam sebuah buku yang berjudul Mengelola Kecerdasan dalam B elajar karangan M asri K uadrat dan Hamzah B Uno dijelaskan bahwa potensi sumber daya manusia merupakan asset nasional sekaligus sebagai modal dasar pembangunan bangsa. Potensi ini hanya dapat digali dan dikembangkan serta dipupuk secara efektif melalui strategi pendidikan dan pembelajaran yang terarah dan terpadu, kemudian dikelola secara serasi dan seimbang dan memerhatikan pengembangan potensi peserta didik secara utuh dan optimal. Karena itu, strategi pendidikan perlu secara khusus memerhatikan pengembangan potensi anak didik yang memiliki kemampuan dan kecerdasan luar biasa (unggul), yakni dengan cara penyelengaraan berbagai macam proses dan segala program pembelajaran yang mampu mengembangkan keunggulan-keunggulan tersebut, baik keunggulan dalam hal potensi intelektual maupun bakat khusus yang bersifat 
keterampilan (gifted and talented). ${ }^{1}$ Potensi dasar yang perlu dikembangkan dari proses pendidikan ialah dari aspek pengetahuan (kognitif) sebelum berlanjut pada aspek lain seperti afektif dan psikomotorik.

Tohirin menjelaskan didalam bukunya bahwa tipe prestasi belajar bidang kognitif mencakup tipe seperti Prestasi Belajar Pengetahuan Hafalan (knowledge) pengetahuan ini mencakup aspek-aspek faktual dan ingatan (sesuatu hal yang harus diingat kembali) seperti batasan, peristilahan, pasal, hukum, bab, ayat, rumus, dan lain-lain. Tipe ini adalah tingkatan tipe prestasi belajar yang paling rendah. Namun demikian, tipe prestasi belajar ini penting sebagai prasyarat untuk mengusai dan mempelajari tipe-tipe prestasi belajar yang lebih tinggi. Sebagai contoh, bagaimana mungkin seorang siswa bisa melakukan shalat dengan baik tanpa ia hafal bacaanbacaan dan urutan-urutan kegiatan yang terkait dengan shalat. Demikian juga untuk ibadah-ibadah lainnya seperti wudhu, tayamum, haji, dan sebagainya. ${ }^{2}$

Untuk mencetak kepribadian anak didik yang cerdas dan berprestasi bukanlah termasuk hal yang mudah bagi pihak penyelenggara pendidikan, perlu cara yang benar-benar baik untuk mengatasi hal ini, pendidik harus mampu menyusun strategi atau cara untuk membentuk suatu pembelajaran atau pengajaran yang mudah di terima serta dipahami oleh peserta didik khususnya pada pembelajaran yang akan diajarkan. Fenomena yang banyak terjadi selama ini yaitu adanya peserta didik yang belum mampu membaca ayat-ayat Al-Qur'an sehingga menjadi hambatan bagi peserta didik dalam menerima materi pelajaran yang didalamnya terdapat ayat-ayat AlQur'an. maka sepatutnya pendidik membuat suatu rancangan strategi terkait dengan pembelajaran agar peserta didik mampu membaca huruf Al-Qur'an. Jika hal itu sudah mampu dicapai oleh peserta didik maka kemudian pendidik berupaya

1 Hamzah B uno, Masri Kuadrat, Mengelola Kecerdasan dalam Belajar, (Jakarta: Bumi Aksara, 2009), h. 2.

${ }^{2}$ Tohirin,Psikologi Pembelajaran Pendidikan Agama Islam,(Jakarta : Raja Grafindo Persada, 2006),h. 151-154. 
mengarahkan agar peserta didik yang tadinya sudah mampu membaca A I-Q ur' an bisa mengahafalkan ayat-ayat A I-Q ur' an.

Dengan adanya siswa yang mampu menghafal dan memiliki hafalan AI-Qur'an akan menjadi modal besar sebagai pengetahuan agama bagi siswa, selain itu kebiasaan menghafal juga bermanfaat bagi siswa yakni dapat membantu peserta didik untuk terbiasa mempertajam ingatannya dengan membiasakan ketelitian untuk menghindari kekeliruan dalam belajar. Itu, semua dirancang agar dapat menumbuh kembangkan prestasi dan kecerdasan belajar.

Sa'dulloh menyebutkan sebelas manfaat dan kegiatan menghafal Al-Qur'an, Diantaranya menghafal Al-Qur'an merupakan bahtera ilmu dan anugerah dari Allah berupa ingatan kuat dan tajam serta pemikiran yang cemerlang, disebut bahtera ilmu karena akan mendorong seseorang yang hafal AI-Qur'an untuk berprestasi lebih tinggi dari temantemannya yang tidak menghafal AI-Qur'an sekalipun umur, kecerdasan, dan ilmu mereka berdekatan. Penghafal A I-Qur'an juga mendapatkan anugerah dari Allah berupa ingatan yang tajam dan pemikiran yang cemerlang. Karena itu, para penghafal AI-Qur'an lebih cepat mengerti, teliti, dan lebih hatihati karena banyak latihan untuk mencocokkan ayat serta membandingkannya dengan ayat lainnya. ${ }^{3}$

Proses penjagaan Al-Qur'an melalui hafalan ini berlangsung dari waktu ke waktu, hingga saat ini masih banyak penghafal AI-Qur'an yang ditemui. Hafalan AI-Qur'an yang berlangsung sejak masa nabi muhammad SAW hingga saat ini mendapat perhatian khusus dalam dunia pendidikan. Banyak perguruan tinggi yang menyediakan beasiswa bagi penghafal A I-Q ur' an diantaranya adalah U niversitas Islam Indonesia (UII) menyediakan beasiswa bagi penghafal 15 juz dan 30 juz, Universitas Islam Negeri Maulana Malik Ibrahim Malang menyediakan beasiswa bagi penghafal minimal $10 \mathrm{Juz}$, Institut Agama Islam Negeri (IAIN) Sultan Amai Gorontalo menyediakan beasiswa bagi penghafal minimal 3 J uz, termasuk

${ }^{3}$ Sa'dulloh, 9 Cara Praktis Menghafal Al-Qur'an (Jakarta: Gema Insani, 2008), h. 21. 
Jurusan Pendidikan Agama Islam IAIN Sultan Amai menyediakan beasiswa bagi penghafal minimal juz 30.

Lembaga-lembaga yang berkonsentrasi dalam menghafal AI-Qur'an banyak didirikan, baik jenjang Sekolah dasar (SD/MI) menengah pertama (SMP/MTs) menengah atas (SM A/A LIY AH) bahkan perguruan tinggi (PT). Madrasah Aliyah A I-Huda misalnya, berdasarkan data yang di peroleh dari salah satu Lembaga Pendidikan Islam yang berada di Kota Gorontalo yaitu Madrasah Aliyah AI-Huda. Dalam pengamatan langsung yang dilakukan oleh peneliti, disana ditemukan ada program tahfiz Al-Qur'an yang dibuat untuk menjawab persoalan terkait buta membaca huruf AI-Qur'an. Program ini diwajibkan bagi setiap siswa untuk diikuti sampai ketahap mampu membaca A I-Qur'an, untuk tahap menghafal selanjutnya adalah pilihan bagi siswa.

Program tahfiz sebagai program khusus belajar membaca dan menghafal A I-Qur'an ialah program yang dibuat untuk menunjang program-program belajar lainnya, program ini dibuat untuk mengarahkan kemampuan anak didik untuk belajar membaca dan menghafalkan Al-Qur'an, karena kemampuan membaca AI-Qur'an adalah hal yang dipandang perlu dikuasai oleh setiap siswa yang menjalani pendidikan di madrasah, kemudian menghafal Al-Qur'an adalah sebuah prestasi bagi siswa untuk mengembangkan potensi mereka masing-masing. sebab dengan kebiasaan menghafal dan mengulang-ualng kembali hafalan kekuatan ingatan peserta didik senantiasa terlatih. Maka dapat disimpulkan dengan program tersebut setiap siswa dibimbing dan dilatih dari tahap dasar, menengah, hingga ketahap menghafal A I-Qur'an.

\section{PEMBAHASAN}

Strategi merupakan suatu aspek penting bagi suksesnya tujuan yang telah direncanakan untuk mencapai sasaran program yang efektif dan efisien, setiap program yang diciptakan pastinya akan menghadapi berbagai masalah atau hambatan baik yang datang dari dalam maupun dari luar sekolah. 
Strategi merupakan pengaturan yang diatur oleh seseorang untuk mencapai suatu tujuan tertentu,dalam konsep mengenai strategi harus dikembangkan terus menerus dan setiap pelaksananya mempunyai gaya dan ciri khas masingmasing. Strategi dalam dunia pendidikan sangat dibutuhkan untu kelangsungan program pendidikan, strategi diharapkan mampu membawa dan mewujudkan visi da misi pendidikan yang telah diterapkan dan mencapai sasaran atau tujuan, baik tujuan jangka panjang maupun tujuan jangka pendek.

Dalam beberapa teori yang dikemukakan oleh pemikir, dapat dikutip salah satu teori yang disampaikan oleh David : bahwa strategi adalah sarana bersama tujuan jangka panjang yang hendak dicapai, strategi pendidikan mecakup ekspansi pembelajaran. Strategi pendidikan adalah aksi potensial oleh pelaksana pendidikan untuk mencapai tujuan pendidikan itu sendiri, hal yang paling utama untuk disentuh oleh strategi adalah peserta didik, sebab peserta didik adalah objek pendidikan yang semestinya diarahkan kepada posisi yang berprestasi. Jadi strategi pendidikan adalah sebuah tindakan aksi sekaligus kegiatan oleh pelaksana pendidikan untuk mencapai tujuan dan sasaran yang telah ditetapkan.

Dalam teori lain hal berkaitan dengan strategi juga diungkapkan oleh Tjiptono bahwa istilah strategi berasal dari bahasa $Y$ unani yaitu strategia yang berartiseni atau keterampilan untuk menjadi seorang jenderal. Hal demikian dikemukakannya dari segi aspek militer. Lain halnya dengan persoalan pendidikan, meski ada aspek yang juga sama, dunia pendidikan juga memerlukan yang namanya strategi, untuk mewujudkan tujuan pendidikan strategi juga dapat berperan sebagai suatu rencana yang dipersiapkan dan dilaksanakan untuk menggapai tujuan pendidikan, strategi juga merupakan rencana terstruktur yang dibuat agar mempermudah suatu proses pendidikan.

Dari beberapa definisi tersebut penulis menyimpulkan bahwa strategi pendidikan berguna untuk mengatur dan mempermudah tujuan-tujuan pendidikan yang telah ditetapkan sebelumnya. 


\section{Pengertian Hafalan Al-Qur'an}

Dalam Kamus Besar Bahasa Indonesia, pengertian menghafal yakni berusaha meresapkan kedalam fikiran agar selalu ingat. ${ }^{4} M$ enurut Zuhairini dan Ghofir sebagaimana yang dikutip oleh Kamilhakimin Ridwal Kamil dalam bukunya yang berjudul M engapa Kita M enghafal (Tahfizh) Al-Qur'an, istilah menghafal adalah suatu metode yang digunakan untuk mengingat kembali sesuatu yang pernah dibaca secara benar seperti apa adanya. M etode tersebut banyak digunakan dalam usaha untuk menghafal A I-Qur'an dan A I-Hadits. ${ }^{5}$

Dalam Kamus B esar Bahasa Indonesia Tahfidz berasal dari Bahasa Arab ( حَفِ يَحْفَظُ حِفْظًا ) yang berarti menghafal, sedangkan kata "menghafal" berasal dari kata "hafal" yang memiliki dua arti : (1) telah masuk dalam ingatan (tentang pelajaran), dan (2) dapat mengucapkan di luar kepala (tanpa melihat buku atau catatan lain). A dapun arti "menghafal" adalah berusaha meresapkan ke dalam pikiran agar selalu ingat. 6

M enurut $A$ hmad Warson M unawwir, kata "menghafal" dalam bahasa Arab adalah "hifzh". Kata ini berasal dari fi'il (kata kerja) : hafizha - yahfazhu - hifzhan. Jika dikatakan, hafizha asysyai'a, artinya menjaga (jangan sampai rusak), memelihara dan melindungi. Namun jika dikatakan, hafizha assirra, artinya katamahu (menyimpan). Dan jika dikatakan, hafizha ad-darsa, artinya istazhharahu (menghafal). ${ }^{7}$

M aka jelaslah diketahui bahwa hafalan adalah sesuatu yang diserap kedalam pikiran yang kemudian terus diingat sebagaimana bentuk aslinya dan dapat disebutkan tanpa harus melihat naskah atau konsep. Dengan demikian dapat dikatakan

${ }^{4}$ Tim Prima Pena, Kamus Besar Bahasa Indonesia, (Jakarta: Gita Media Press,tt). h. 307

${ }^{5}$ http://pksaceh.net/mengapa-kita-menghafal-tahfidzh-alqur\%E2\%80\%99an/ Diakses 02 Desember 2017

${ }^{6}$ Poerwadarminta, Kamus Besar Bahasa Indonesia,(Jakarta: Duta Rakyat, 2002) h. 381

7 Ahmad Warson Munawwir, Kamus Al-Munawwir, (Yogyakarta: Pustaka Progressif, 1997), h. 279 
bahwa proses menghafal mencakup tiga tahapan, yaitu proses memasukkan, menyimpan, dan mengingat kembali informasi.

M enurut A nshori A I-Qur' an secara bahasa diambil dari kata: قرا - قرا - قران yang berarti sesuatu yang dibaca. A rti ini mempunyai makna anjuran kepada umat Islam untuk membaca Al-Qur'an. AI-Qur'an juga bentuk mashdar dari القران yang berarti menghimpun dan mengumpulkan. Dikatakan demikian sebab seolah-olah A I-Q ur' an menghimpun beberapa huruf, kata, dan kalimat secara tertib sehingga tersusun rapi dan benar. ${ }^{8}$

M. Quraish Shihab mengemukakan bahwa para ulama berbeda pendapat dalam memberikan definisi terhadap AlQur'an. A da yang mengatakan bahwa A I-Qur'an adalah kalam Allah yang bersifat mu'jizat yang diturunkan kepada $\mathrm{Nabi}$ Muhammad SAW melalui perantara Jibril dengan lafal dan maknanya dari Allah SWT, yang dinukilkan secara mutawatir; membacanya merupakan ibadah; dimulai dengan surah alFatihah dan diakhiri dengan surah an-N as. ${ }^{9}$

M enurut M . Quraish Shihab, A I-Q ur' an secara harfiyah berarti bacaan yang sempurna. Ia merupakan suatu nama pilihan Allah yang tepat, karena tiada suatu bacaanpun sejak manusia mengenal tulis baca lima ribu tahun yang lalu yang dapat menandingi A I-Q ur' an, bacaan sempurna lagi mulia. ${ }^{10}$

Strategi hafalan A I-Qur' an yakni strategi yang dibuat untuk mengarahkan peserta didik untuk dapat belajar A I-Qur'an diantaranya adalah menghapalkan ayat-ayat Al-Qur'an tersebut, strategi ini juga perlu dibuat agar memaksimalkan belajar Al-Qur'an untuk dapat memperoleh hasil belajar yang baik.

\section{Hakikat Hasil B elajar}

K amus Lengkap Bahasa Indonesia menyatakan hasil belajar merupakan kata majemuk yang terdiri dari kata hasil dan belajar. Hasil belajar ini merupakan salah satu alat ukur

${ }^{8}$ Anshori, Ulumul Quran, (Jakarta: Rajawali Press, 2013), h.17

${ }^{9}$ M. Quraish Shihab, et. all., Sejarah dan Ulum Al-Qur'an, (Jakarta: Pusataka Firdaus, 2008), h. 13.

10 M. Quraish Shihab, Wawasan Al-Qur'an, (Bandung: Mizan, 1996), h.3 
tingkat keberhasilan seorang siswa di dalam kegiatan proses belajar mengajar yang diikutinya di sekolah. Dengan demikian, seorang siswa mendapat prestasi belajar minimal dalam batas rangking tertentu, sering dikatakan siswa tersebut berhasil. Dalam Kamus Besar Bahasa Indonesia, kata prestasi diartikan sebagai, "hasil yang telah dicapai", prestasi sebagai hasil suatu kegiatan yang telah dikerjakan, diciptakan, baik secara individual maupun kelompok. ${ }^{11}$

Menurut Suharsimi A rikunto hasil belajar dapat ditentukan oleh beberapa faktor dalam kegiatan proses pembelajaran di sekolah antara lain:
a. Siswa sendiri
b. Guru dan personal lainnya
c. Bahan pengajaran
d. M etode mengajar dan sistem evaluasi
e. Sarana penunjang
f. Sistem administrasi. ${ }^{12}$

Menurut Sardiman Am Prestasi/Hasil Belajar adalah kemampuan nyata yang merupakan hasil interaksi antara berbagai faktor yang mempengaruhi baik dari dalam maupun dari luar diri individu dalam belajar. ${ }^{13}$

Tulus Tu'u merumuskan Hasil belajar sebagai berikut:

a. Prestasi belajar siswa adalah hasil belajar yang dicapai siswa ketika mengikuti dan mengerjakan tugas dan kegiatan pembelajaran di sekolah.

b. Prestasi belajar siswa tersebut terutama dinilai aspek kognitifnya karena yang bersangkutan dengan kemampuan siswa dalam pengetahuan atau ingatan, pemahaman, aplikasi, analisis, sistesa dan evaluasi.

c. Prestasi belajar siswa dibuktikan dan ditunjukkan melalui nilai dari hasil evaluasi yang dilakukan oleh guru terhadap

11 Kamisa, Kamus Lengkap Bahasa Indonesia, (Surabaya: Kartika, 1997), 418

12 Suharsimi Arikunto, Dasar-dasar Evaluasi Pendidikan,( Jakarta: Bumi Aksara, 2008), h. 5

${ }^{13}$ Anshori, Ulumul..., 46 
tugas siswa dan ulangan-ulangan atau ujian yang ditempuhnya. ${ }^{14}$

Tulus Tu'u juga mengemukakan bahwa prestasi belajar siswa terfokus pada nilai atau angka yang dicapai siswa dalam proses pembelajaran di sekolah. Nilai tersebut terutama dilihat dari sisi kognitif, karena aspek ini yang sering dinilai oleh guru untuk melihat penguasaan pengetahuan sebagai ukuran pencapaian hasil belajar siswa. Nana Sudjana mengatakan bahwa pada ketiga ranah ini yakni, kognitif, afektif dan psikomotorik, maka ranah kognitiflah yang paling sering dinilai oleh para guru di sekolah karena berkaitan dengan kemampuan para siswa dalam menguasai isi bahan pengajaran. Karena itu unsur yang ada dalam prestasi siswa terdiri dari hasil belajar dan nilai siswa. ${ }^{15}$

Berdasarkan kajian teori di atas dapat disimpulkan bahwa prestasi belajar merupakan hasil belajar seseorang yang diperoleh dari suatu proses pembelajaran dan hasil belajar yang diperolehnya merupakan hasil dari evaluasi atau penilaian yang dilakukan oleh guru kepada siswanya. Penilaian tersebut diinterprestasikan dalam bentuk nilai. Maka jelaslah bahwa prestasi belajar itu adalah hasil maksimal yang diperoleh siswa dalam jangka waktu tertentu setelah mengikuti berbagai program latihan dan program pengajaran yang telah disusun dan direncanakan sedemikian rupa.

\section{Faktor-Faktor yang M empengaruhi Hasil Belajar}

Menurut Muhibbin Syah dan Agus Efendi ada beberapa faktor yang mempengaruhi hasil belajar, yaitu faktor internal dan faktor eksternal. Faktor internal mencakup : kecerdasan emosional, intelligensi, sikap, bakat, minat dan motivasi. Sedangkan faktor eksternal meliputi: lingkungan keluarga, sekolah, dan masyarakat. ${ }^{16}$ Berikut ini akan di jelaskan masing-masing aspek:

14 Tulus Tu'u, Peran Disiplin pada Perilaku dan Prestasi Siswa, (Jakarta : Grasindo, 2004), 76

${ }^{15}$ Ibid., 58

${ }^{16}$ Muhibbin Syah, Psikologi Pendidikan dengan Pendekatan Baru,( Bandung: Remaja Rosdakarya, 2010), 129. 
a. Faktor Internal Siswa

1. Kecerdasan Emosional

Kecerdasan Emosional adalah kemampuan mengenali perasaan diri sendiri dan perasaan orang lain, kemampuan memotivasi diri sendiri, dan kemampuan mengelola emosi dengan baik pada diri sendiri dan dalam hubungannya dengan orang lain.K ecerdasan emosional adalah kcerdasan yang sangat diperlukan untuk berprestasi. ${ }^{17}$

Menurut Agus Efendi kecerdasan Emosional merupakan faktor penting dalam perkembangan intellektual anak, hal ini sejalan dengan pandangan semiawan bahwa stimulasi intelektual sangat dipengaruhi oleh keterlibatan emosional, bahkan emosi juga amat menentukan perkembangan intelektual anak secara bertahap. A rtinya secara timbal balik faktor kognitif juga terlibat dalam perkembangan emosional.18

2. Intelligensi

Intelligensi merupakan istilah umum untuk menggambarkan kepintaran dan kepandaian seseorang. Suharsono menyebutkan bahwa intelligensi adalah kemampuan untuk memecahkan masalah secara benar. Intelligensi ini dapat diartikan sebagai kemampuan psikofisik untuk mereaksi rangsangan atau menyesuaikan diri dengan lingkungan dengan cara yang tepat. Tingkat intelligensi siswa tidak dapat diragukan lagi sangat menentukan tingkat keberhasilan siswa. Intelligensi besar pengaruhnya terhadap kemajuan dan hasil belajar. Siswa yang mempunyai tingkat intelligensi tinggi akan lebih berhasil dari siswa yang mempunyai tingkat intelligensi yang rendah. ${ }^{19}$

Alfabeta,2005), 171

17 Agus Efendi, Revolusi Kecerdasan Abad 21 (Bandung:

18 Hamzah B. Uno, Perencanaan Pembelajaran, (Jakarta: Bumi Aksara, 2006), h. 80.

${ }^{19}$ www.Kompasiana.com/intelegensi/faktorbelajardankecerdasan26 826666723L::LL>>?><?> diakses tanggal 5 januari 2019 


\section{Sikap}

Muhibbin Syah mendefinisikan sikap adalah gejala internal yang berdimensi afektif berupa kecenderungan untuk mereaksi dengan cara yang relatif tetap terhadap obyek orang, barang, dan sebagainya, baik secara positif maupun negative. ${ }^{20}$

Sikap yang positif terhadap mata pelajaran, dapat memberikan pengaruh yang positif terhadap proses belajar. Sebaliknya, sikap yang negatif terhadap mata pelajaran, akan menimbulkan kesulitan belajar.

4. M otivasi

Sardiman A.M mengemukakan motivasi dapat diartikan sebagai upaya yang mendorong seseorang untuk melakukan sesuatu. M otivasi dapat juga diartikan sebagai daya penggerak dari dalam dan di dalam subyek untuk melakukan aktivitas-aktivitas tertentu demi mencapai suatu tujuan. ${ }^{21}$

M otivasi belajar pada dasarnya mempengaruhi tingkah laku belajar. M otivasi adalah sebagai penggerak tingkah laku dan sangat penting dalam proses belajar. Siswa yang memiliki motivasi tinggi dalam belajar, maka prestasi belajarnya akan optimal, sebaliknya siswa yang memiliki motivasi rendah dalam belajar, maka prestasi belajarnya di sekolah tidak akan meningkat.

b. Faktor Eksternal Siswa

1. Lingkungan K eluarga

Monty P. Satiadarma \& Fidelis menuliskan didalam bukunya Setiap orang memulai kehidupannya di dalam keluarga. Lingkungan keluarga besar atau kecil mempunyai pengaruh pada pertumbuhan dan perkembangan anak. Posisi seseorang dalam keluarga yang merawatnya berpengaruh pada fungsi belajarnya.

${ }^{20}$ Muhibbin Syah, Psikologi Pendidikan dengan Pendekatan Baru, (Bandung: Remaja Rosdakarya, 2010), h. 132.

21 Sardiman A.M, Interaksi dan Motivasi Belajar Mengajar, (Jakarta:Rajawali, 1992), h. 73. 
Studi lain menunjukan bahwa penampilan sikap orang tua berperan penting dalam memajukan atau menghambat pendidikan seseorang. ${ }^{22}$ Bimbingan dari orang tua juga merupakan salah satu aspek yang sangat penting dalam keberhasilan siswa dalam belajar. Bimbingan itu bisa membuat siswa akan terdorong belajar secara aktif, karena bimbingan merupakan salah satu kekuatan pendorong dari luar yang menambah motivasi dalam belajar.

2. Lingkungan Sekolah

Sekolah merupakan lembaga pendidikan formal yang secara sistematis melaksanakan program bimbingan, pengajaran, atau pelatihan dalam rangka membantu para siswa agar mampu mengembangkan potensinya secara optimal, baik yang menyangkut aspek moral-spiritual, intelektual, emosional, sosial, maupun fisik-motoriknya.

Syamsu Y usuf dan Nani M didalam bukunya mengutip definisi yang dikemukakan Harlock bahwa sekolah merupakan faktor penentu bagi perkembangan kepribadian anak, baik dalam cara berfikir, bersikap, maupun berperilaku. ${ }^{23}$

Lingkungan sekolah mempunyai peranan yang sangat penting dalam meningkatkan prestasi belajar siswa, seperti adanya sarana dan prasarana yang memadai, metode mengajar, kurikulum, dan alat-alat pelajaran seperti buku pelajaran, alat olah raga dan sebagainya. Dengan demikian lingkungan sekolah sangat mendukung prestasi belajar siswa di sekolah.

3. Lingkungan M asyarakat

M enurut M uhibbin Syah lingkungan sosial siswa adalah masyarakat dan tetangga juga teman-teman sepermainan di sekitar perkampungan siswa tersebut.

22 Monty P. Satiadarma \& Fidelis, Mendidik Kecerdasan ( Jakarta: Bumi Aksara, 2009), h. 122-123.

23 Syamsu Yusuf dan Nani M, Perkembangan Peserta Didik ( Jakarta: Rajawali Pers, 2011), h. 30 
Kondisi masyarakat di lingkungan kumuh yang serba kekurangan dan anak-anak penganggur, misalnya, akan sangat mempengaruhi aktivitas belajar siswa. Paling tidak siswa tersebut akan menemukan kesulitan ketika memerlukan teman belajar atau berdiskusi atau meminjam alat-alat belajar tertentu yang kebetulan belum di milikinya. ${ }^{24}$

\section{Hafalan AI-Qur'an Peserta Didik di Madrasah Aliyah Al-Huda Kota Gorontalo}

M enurut N urdin Si'u siswa yang akan menghafal harus memiliki dua hal yakni kemauan dan waktu yang cukup untuk menghapal dan mengulang-ulang hafalan yang sudah ada dan siswa harus mempersiapkan satu mushaf Al-Qur'an yang digunakan untuk menghapal, menyediakan satu mushaf khusus adalah hal yang terpenting. dengan satu mushaf yang diperbiasakan untuk digunakan akan menguatkan ingatan siswa tentang tata letak ayat AI-Qur'an sehingga nanti pada proses pengulangan hafalan siswa akan membayang-bayangkankan gambaran posisi ayat AI-Qur'an yang terletak pada mushaf tersebut. Guru akan menghimbau kepada seluruh siswa agar tidak membiasakan mengganti-ganti mushaf agar potretan tentang tata letak ayat tidak terganti. ${ }^{25}$

Saat proses menghapal guru akan memberikan waktu kepada siswa untuk menyediakan hafalan, waktu yang diberikan adalah ketika siswa berada dirumah dengan metode siswa mendengarkan audio selama satu jam berulang-ulang tentang ayat yang akan dihapalkan nanti, dan setelah didengarkan siswa membacanya berulang-ulang, hal ini disampaikan guru ketika disekolah kemudian dikerjakan siswa ketika berada dirumah, saat hari berikut siswa kambali lagi ke sekolah guru akan mengarahkan siswa untuk menghapal dengan pemberian waktu 15 sampai dengan 30 menit kemudian siswa langsung menyetorkan hafalannya.

${ }^{24}$ Muhibbin Syah, Psikologi Pendidikan dengan pendekatan baru, (Bandung: Remaja Rosdakarya, 2010), h. 135

${ }^{25}$ Nurdin Si'u, Guru Tahfidz MA Al-Huda, wawancara, di Kota Gorontalo Tanggal 7 Juni 2019. 
Nurdin Si'u mengungkapkan jika arahan guru itu dimaksimalkan oleh siswa maka capaian hafalan setiap kali menyetorkan hafalan sampai dengan satu halaman, jumlah hafalan yang disetorkan disesuaikan dengan tingkat kemudahan ayat Al-Qur'an tersebut karena kemampuan siswa tidak seluruhnya sama, namun capaian hafalan setiap harinya adalah satu halaman AI-Qur'an dengan metode penyetoran yang berbeda-beda dari setiap siswa, ada siswa yang menyetorkan hafalan satu halaman sekaligus dan ada juga yang menyetorkan satu halaman hafalan dengan cara bertahap yakni menyetorkan setengah halaman kemudian dengan selingan waktu lima menit disetorkan kembali setengah berikutnya. Pada intinya guru menentukan target dalam satu pekan jumlah hafalan yang harus diperoleh siswa adalah dua setengah lembar kemudian dengan hari yang tersisa dalam sepekan digunakan siswa untuk memperlancar hafalan yang sudah dihapalkan. Dalam perolehan hafalan setiap bulan diadakan tasmi' hafalan berguna untuk mengevaluasi jumlah dan kualitas hafalan. Dengan progres tersebut maka jumlah hafalan yang diperoleh siswa selama satu bulan adalah satu juz dengan begitu total hafalan dalam satu semester adalah lima sampai dengan enam juz. ${ }^{26}$

Bagaimana dengan suasana menghafal yang baik. Nurdin Si'u mengatakan saat proses menghapal siswa membutuhkan kondisi suasana yang kondusif, kondisi dimana siswa tidak memiliki gangguan dalam artian suasana yang tenang, dengan begitu siswa dengan mudah untuk membuat hafalan, tidak cukup sampai disitu hal-hal lain yang dapat mengganggu dari kegiatan menghapal musti dijauhi oleh siswa, seperti gadget dan benda-benda lain yang dapat mengganggu proses menghapal, sehingga dengan demikian dapat tercipta kondisi suasana yang tenang dan bersemangat untuk menghapal, biasanya siswa diarahkan ke musholla/masjid sekolah untuk mencari suasana yang aman dari kebisingan dan aman dari dari hal-hal yang mengganggu. ${ }^{27}$

${ }^{26}$ Nurdin Si'u, Guru Tahfidz MA Al-Huda, wawancara, di Kota Gorontalo Tanggal 7 Juni 2019.

27 Nurdin Si'u, Guru Tahfidz MA Al-Huda, wawancara, di Kota Gorontalo Tanggal 7 Juni 2019. 
Selanjutnya guru menyampaikan tata cara untuk memelihara hafalan agar terus bertahan dalam ingatan yaitu dengan cara sering kali mengulang-ulangnya setiap hari, saat yang paling baik untuk mengulang hafalan ketika melaksanakan sholat, membawakan ayat yang telah dihapal ketika sholat akan menambah daya ingat yang kuat, sebab disaat berdiri sholat, pikiran akan berusaha mengingat dan memunculkan hafalan yang telah dihapal baik dalam sholat wajib maupun sholat sunnah. Siswa juga dianjurkan untuk selalu berdo'a, beribadah dan menjuhi perbuatan-perbuatan dosa, sebab melakukan maksiat akan membuat susah ketika menghapal.

Dari kegiatan menghapal disekolah dan dirumah adalah tanggung jawab peserta didik, menurut Taufiq Biahimo siswa yang saat ini telah duduk dibangku kelas dua belas mengemukakan bahwa menghapalkan ayat-ayat AI-Qur'an adalah hal yang mudah. ${ }^{28}$ Namun dengan kemudahan itu bukan berarti setelah dihapalkan kemudian tidak diulang lagi, tanggung jawab seorang penghapal Al-Qur'an lebih besar pada proses memelihara hafalan agar tetap diingat secara terus menerus. ${ }^{29}$

Dengan kebiasaan menghapal dan memelihara hafalan yang selalu dibudayakan kepada siswa, siswa senantiasa terbiasa dalam hal memperhatikan dan setiap kali teliti dalam membaca, jika hal ini sudah menjadi kebiasaan, tentu akan berpengaruh ketika siswa belajar pada umumnya dan ketika sudah berpengaruh kepada kebiasaan belajar siswa, maka akan berdampak baik pada hasil belajar siswa pada mata pelajaran lain khususnya pelajaran yang membidangi atau kandungan materinya memuat ayat-ayat A I-Qur'an.

Selain kegiatan menghafal dengan mengikuti program tahfiz peserta didik senantiasa terlatih untuk mempermantap bacaan A I-Qur' an mengetahui penerapan ilmu tajwid yang baik dan benar.

Adapun mengenai hafalan Al-Qur'an siswa di M adrasah Aliyah A L-Huda Gorontalo, berdasarkan wawancara

28 Taufiq Biahimo, Siswa MA Al-Huda, Wawancara, di Kota Gorontalo Tanggal 7 Juni 2019

29 Taufiq Biahimo, Siswa MA Al-Huda, wawancara, di Kota Gorontalo Tanggal 13 Juni 2019. 
yang dilakukan kepada beberapa siswa yang dijadikan sebagai informan penelitian, sebagian besar siswa yang mengikuti kegiatan hafalan A I-Qur'an sudah memiliki hafalan A I-Qur'an sebanyak 3-5 juz bahkan ada yang sudah mampu menghafalkan AI-Qur'an sebanyak 6-7 juz. Hal ini membuktikan berjalan baiknya program hafalan A I-Qur' an yang dijalankan di M adrasah A liyah A lhuda K ota Gorontalo.

Strategi Implementasi Hafalan AI-Qur'an Siswa Di Madrasah Aliyah A I-Huda K ota Gorontalo

Dalam kegiatan pelaksanaan pendidikan madrasah yang didominasi dengan pelajaran keagamaan tentunya hasil dari pendidikan harus menghasilkan siswa yang mahir dalam keilmuan agama, karena pendidikan keagamaan didalam lingkungan madrasah adalah ikon penting yang mesti dikedepankan, maka dari itu dalam mencapai tujuan pendidikan itu hal yang paling mendasar untuk direalisasikan adalah siswa yang mampu untuk memiliki hafalan AI-Qur'an, karena pada dasarnya hafalan A I-Qur' an akan menjadi awal yang paling baik sebelum siswa mendalami keilmuannya dibidang keagamaan lainnya, karena Al-Qur'an adalah induk dari pengetahuan agama, melihat dari hal itu maka guru harus menciptakan strategi atau cara supaya siswa dapat menghapalkan A I-Q ur' an.

M enurut Nurdin Si'u dalam memulai merancang suatu strategi tentunya ada persiapan awal yang harus disiapkan oleh seorang guru, karena guru tidak hanya berhadapan dengan satu orang siswa saja melainkan guru harus mengarahkan seluru siswa dengan strategi menghapal yang mudah. Maka pemilihan serta perancangan suatu strategi harus benar-benar mampu mengarahkan seluruh siswa agar bisa dengan mudah untuk menghapalkan ayat-ayat dalam AI-Qur'an. Hal yang perlu diperhatikan oleh guru untuk memulai membuat strategi adalah target, sebab dengan sebuah target guru bisa memperkirakan sejauh mana kemampuan siswa dalam menghapal serta sudah berapa banyak perolehan hafalan siswa dalam jumlah hari yang telah ditentukan guru, dengan menentukan target tersebut guru 
bisa memantau pervorma serta hambatan yang dihadapi siswa selama proses menghapal. ${ }^{30}$

Menurut Nismawati kebiasaan menghafal adalah anugerah dari Allah Swt berupa kesempatan untuk ikut memelihara ayat-ayat Allah Swt, tidak banyak orang bisa melakukan hal demikian. Seluruh siswa yang menghafal AlQur'an mereka oreng-orang yang cerdas, memiliki daya ingat yang kuat hal ini dibuktikan pada setiap kali saya memberikan pembelajaran dikelas.

Untuk memperjelas maksud daripada Strategi Implementasi Hafalan A I-Qur' an Terhadap Hasil B elajar Siswa maka dapat dibagi menjadi dua pembahasan lebih lanjut yaitu; (1) Strategi Menghafal AI-Qur'an, dan (2) Menghafal AIQur'an Sebagai Strategi Belajar.

1. Strategi M enghafal AI-Qur'an

M enurut Nurdin Si'u strategi daripada menghafal A IQur'an sebelumnya yang perlu dimunculkan itu adalah kemauan siswa untuk menghafal, siswa yang berkemauan tinggi akan sabar dalam melalui tingkatan proses menghapal sampai kepada ketentuan target, disetiap kondisi siswa diharapkan untuk tidak berputus asa ketika menemukan dan menyerap ayat yang sedikit tidak mudah untuk dihapalkan, pemberian motifasi oleh guru kepada siswa itu sangat berpengaruh kepada kemauan siswa dalam tahap persiapan sebelum menghafal. ${ }^{31}$

Nurdin Si'u juga mengemukakan setelah usaha membangkitkan kemauan atau semangat siswa untuk menghafal guru wajib mengetahui tingkat kemampuan siswa dalam membacakan ayat Al-Qur'an melalui proses tahsin, kemampuan siswa dalam membaca A I-Q ur' an serta penguasaan terhadap hukum-hukum bacaan tajwid dalam AI-Qur'an akan mempengaruhi kualitas hafalan siswa nantinya, hal demikian perlu diketahui oleh guru sebelum menerapkan strategi karena pada situasi ini guru akan melihat jenis strategi yang cocok untuk dibuat dan diterapkan, pembuatan strategi adalah hal

${ }^{30}$ Nurdin Si'u, Guru Tahfidz MA Al-Huda, wawancara, di Kota Gorontalo Tanggal 7 Juni 2019.

31 Nurdin Si'u, Guru Tahfidz MA Al-Huda, wawancara, di Kota Gorontalo Tanggal 7 Juni 2019. 
yang benar-benar betul diteliti dengan baik agar tidak menimbulkan kesalahan yang nantinya akan memberatkan siswa, strategi memang akan mempermudah siswa jika penerapannya tepat sebaliknya strategi yang kurang tepat akan membuat siswa sulit dalam menjalani proses menghapal nantinya. ${ }^{32}$

Dari evaluasi guru terhadap kualitas bacaan siswa lalu masuk ke pembiasaan siswa untuk membaca, guru akan mengajak siswa untuk senantiasa terbiasa dengan lafaz-lafaz ayat AI-Qur'an, guru berusaha menanamkan budaya membaca A I-Q ur' an secara berulang-ulang kepada siswa agar penyebutan lafaz Al-Qur'an tidak terdengar kaku ketika didengarkan. Setelah tahap ini selesai barulah guru memberikan tugas menghapal dengan target yang telah ditentukan.

A dapun Strategi dan sistem hafalan AI-Qur'an yang berada di Madrasah Aliyah Al-Huda secara rinci seperti yang di ungkapkan oleh guru Pembina tahfiz Al-Qur'an, di M adrasah A liyah A I-Huda di antaranya ialah sebagai berikut;

$Y$ ang Pertama Setoran Hafalan, Sistem setoran hafalan ini di lakukan secara rutin setiap hari, siswa yang sudah menghafal AI-Qur'an mereka menyetorkan hafalannya. Dalam pelaksanaannya, sistem setoran hafalan ini siswa dapat menyetorkan hafalannya dengan guru pembina tahfiz A I-Q ur' an langsung, ataupun juga dengan tutor teman sebaya. Siswa yang mengikuti kegiatan hafalan A I-Qur'an dibagi kedalam beberapa kelompok, di mana tiap-tiap kelompok tersebut dipegang oleh salah satu siswa yang memang hafalannya lebih banyak diantara teman-teman yang lainnya. Dalam menyetorkan hafalan dilaksanakan sesuai kemampuan siswa, artinya tidak ada paksaan harus sekian ayat.

$Y$ ang Kedua Muroja'ah, Sistem muroja'ah ini dilakukan setiap hari jum'at dan sabtu siang, dalam pelaksanaannya sama dengan sistem setoran hafalan ada yang ke pembina tahfiz langsung dan ada yang ke teman sebaya. siswa mengulang ayat per ayat dan juga di sarankan untuk

${ }^{32}$ Nurdin Si'u, Guru Tahfidz MA Al-Huda, wawancara, di Kota Gorontalo Tanggal 7 Juni 2019. 
mendengarkan hafalan A I-Qur'an melalui media audio visual baik melalui MP3 ataupun lainnya yang dapat menjadi bahan untuk menambah hafalan siswa. Kegiatan muroja'ah ini dilakukan guna menjaga hafalan siswa agar tidak lupa setelah menyetorkannya.

$Y$ ang Ketiga Evaluasi, kemampuan menghafal AlQurean siswa bertujuan untuk mengukur sejauh mana kemampuan menghafal Al-Qurean siswa. kegiatan evaluasi menghafal AI-Qur'an di Madrasah Aliyah A I-Huda Gorontalo ini di namakan dengan ujian Sima'an. Kegiatan ujian ini di adakan setiap akhir bulan, bagi yang lulus ujian bisa langsung melanjutkan hafalan juz selanjutnya, dan bagi yang belum lulus diberi waktu untuk mengulang hafalannya dan diberi kesempatan ujian gelombang berikutnya.

Dari ketiga strategi dan sistem menghafal tersebut dapat disimpulkan yang pertama setoran hafalan dilakukan untuk menambah hafalan siswa, muroja'ah dilakukan agar hafalan yang sudah dihafalkan tidak cepat lupa dengan cara mengulang-ulang hafalan, dan yang ketiga evaluasi atau sima'an Al-Qur'an dilakukan untuk mengukur kemampuan siswa tentang kelancaran hafalan yang sudah dihafalkan.

Fungsi strategi yang dibuat tentunya akan memudahkan siswa ketika menghapal menuju target, yang terpenting adalah bukan banyaknya hafalan melainkan kualitas hafalan, kualitas hafalan yang dimaksud ialah hafalan yang bertahan lama dalam ingatan dengan pengucapan lafaz yang baik dan benar, maka dari itu strategi yang dibuat adalah proses siswa yang menghapal tidak terburu-terburu dengan banyaknya jumlah hafalan, meski prosesnya lambat yang terpenting hafalan yang diperoleh siswa tidak mudah lupa dan pengucapannya benar.

Adapun strategi lain yang dilakukan guru yaitu simulasi pra menghapal guru juga menyediakan audio pengajian AI-Qur'an oleh beberapa syekh yang murattal AI-Qur'annya sering diperdengarkan kepada peserta tahfidz sebagai contoh untuk mereka ikuti.

Fungsi dan hasil dari implementasi strategi tersebut agar siswa tidak kaku dalam menghapal, justru akan 
mempermudah siswa. Siswa yang menghapal akan terbiasa teliti serta mengasah kemampuan berpikir saat mengingat ayat yang telah dihapal, kebiasaan ini akan terbawa ketika belajar. Dengan memiliki hafalan siswa dengan mudah katika berhadapan dengan materi pembelajaran yang memuat ayatayat suci AI-Qur'an.

2. Menghafal A I-Qur' an Sebagai Strategi Belajar.

Di Madrasah Aliyah Al-Huda Kota Gorontalo menghafal Al-Qur'an menjadi suatu strategi belajar, pihak pendidik di Madrasah Aliyah Al-Huda meyakini dengan dimaksimalkan program tahfiz akan menumbuh kembangkan prestasi belajar siswa, setiap siswa yang menghafal A I-Qur'an diyakini memiliki kemampuan yang berbeda dengan siswa yang tidak menghafal A I-Qur'an.

Beberapa fakta ditemukan seperti yang diungkapkan oleh seorang guru mata pelajaran matematika Nismawati Paneo sebagi berikut;

Setiap kali saya masuk memberikan pembelajaran dikelas yang siswanya sebagian aktif mengikuti kegiatan menghafal, saya melihat mereka memiliki kemampuan yang luar biasa dalam memahami materi pelajaran yang diberikan, daya tangkap serta daya ingat mereka sangat baik, hal ini dibuktikan ketika saya menjelaskan materi terkait logaritma, rata-rata dari mereka langsung cepat memahami penjelasan saya. ${ }^{33}$

Dari penjelasan informan diatas dapat dilihat bahwa kemampuan atau daya tangkap dari siswa yang menghafal sangat luar biasa, sebab kemampuan-kemampuan tersebut terlahir dari sebuah kebiasaan yang dilakukan setiap hari, kala berada dirumah maupun disekolah, dari kebiasaan menghafal daya ingat siswa akan selalu terlatih, karena menghafal adalah sebuah proses menyerap sesutu yang dihafalkan dengan membutuhkan konsentrasi dan ketelitian.

${ }^{33}$ Nismawati Paneo, Guru Matematika, Wawancara di Madrasah Aliyah Al-Huda Kota Gorontalo, Tanggal 31 Juli 2019 
Menghafal AI-Qur'an sebagai salah satu strategi belajar untuk mencetak siswa-siswa yang berprestasi baik dari aspek kognitifnya, afektif, dan psikomotorik. Kegiatan menghafal didukung penuh oleh seluruh guru, karena dengan kegiatan demikian dapat membantu meningkatkan pengetahuan serta prestasi belajar dari setiap siswa.

Jika diamati kegiatan menghafal AI-Qur'an sangat membantu mata pelajaran A gama, karena seperti yang kita ketahui bahwa dari materi-materi mata pelajaran agama tersebut yakni Fiqih, A I-Q ur' an Hadist, SKI, A kidah A khlaq. Pastinya memuat ayat-ayat Al-Qur'an yang menjelaskan hukum, sejarah, dan ibadah. M aka denga kegiatan menghafal tersebut secara langsung siswa sudah memiliki hafalan ayatayat tersebut lebih dulu, sehingga ketika masuk pada kegiatan belajar mengajar guru tinggal menjelaskan daripada makna ayat dimaksud.

\section{Hasil Belajar Siswa Di Madrasah Aliyah Al-Huda Kota Gorontalo}

Tercapainya hasil belajar yang memuaskan tentunya adalah harapan bagi setiap lembaga pendidikan. Madrasah Aliyah Al-Huda khususnya, yayasan pendidikan yang berdiri sejak 1929 ini sudah melahirkan banyak lulusan atau alumni terbaik yang telah tersebar dimana-mana, sampai saat ini Madrasah Aliyah Al-Huda terus berusaha melahirkan alumni yang berkualitas. Tata kelola pendidikannya terus ditingkatkan agar bisa bersaing diera abad 21, dengan adanya program tahfidz Al-Qur'an diharapkan mampu menunjang untuk mencapai hasil belajar siswa yang sangat memuaskan dalam bidang A I-Qur' an khususnya.

Imaniar seorang guru mata pelajaran Al-Qur'an Hadis mengemukakan bahwa proses belajar Al-Qur'an Hadist yang sering kita jumpai banyak memuat ayat-ayat AI-Qur'an yang mesti dihapalkan oleh peserta didik untuk mencapai tujuan pembelajaran, oleh karena itu bidang studi ini turut 
mengevaluasi hasil belajar siswa terkait tingkatan hafalan AlQur'an. ${ }^{34}$

Pada mata pelajaran IImu Al-Qur'an Tajwid adalah mata pelajaran yang terfokus pada tata cara atau kaidah membaca AI-Qur'an yang baik dan benar, mata pelajaran ini turut mengevaluasi hasil belajar siswa pada program tahfidz. Bidang studi ini biasanya melakukan evaluasi dengan beberapa tahap yang meliputi tahsin, tajwid, tahfidz. Tahsin adalah sebuah proses mengetahui standar kemampuan dasar seorang peserta didik dalam membacakan ayat-ayat AI-Qur'an, Tajwid adalah sebuah proses mengetahui kemampuan peserta didik dalam penerapan kaidah membaca AI-Qur'an yang baik dan benar, proses ini meliputi penerapan Makhrijul Hurup, Hukum Bacaan Ikhfa, Iqlab, Idhar, Idgham dan semisalnya. Selanjutnya, Tahfidz wa tasmi' adalah sebuah proses mengetahui tingkatan hafalan ayat-ayat Al-Qur'an yang dimiliki oleh peserta didik, proses ini biasanya dilakukan dengan cara tasmi' ialah mendengarkan hafalan ayat yang dibacakan peserta didik melalui beberapa pertanyaan penyambungan ayat.

Berdasarkan data yang diperoleh pada saat melakukan wawancara dengan salah seorang guru yang juga sebagai wakil kepala sekolah bidang kesiswaan mengungkapkan bahwa setiap siswa yang terbiasa menghapal Al-Qur'an memiliki daya tangkap yang cepat dan ingatan yang kuat terhadap setiap materi pembelajaran yang diberikan, hal ini dibuktikannya dengan setiap kali ia masuk mengajar pada jam pelajaran disetiap kelas.

Menurut Nismawati setiap siswa yang terbiasa menghafalkan Al-Qur'an memiliki potensi besar dalam berprestasi disekolah karena memiliki kecerdasan dan ingatan sekaligus daya tangkap yang kuat. ${ }^{35}$

Menurut Suharmin Alinti Dari keseluruhan siswa yang menjadi penghafal A I-Qur' an mereka memiliki kondisi

${ }^{34}$ Imaniar, Guru Mata Pelajaran Al-Qur'an Hadist, Wawancara, Di Kota Gorontalo Tanggal 17 Juni

35 Nismawati, Wakil Kepala Sekolah Bidang Kesiswaan, wawancara, di Kota Gorontalo Tanggal 19 Juni 2019 
psikologis yang baik, sebab membuat hafalan serta menyetorkannya harus dalam keadaan hati dan pikiran yang tenang, hal ini senantiasa mereka lakukan setiap hari hingga terbiasa, dengan begitu pikiran dan daya tangkap mereka kuat, jadi bagaimana mungkin mereka tidak dapat berprestasi sedang kebiasaan mereka terus melatih otak mereka setiap hari baik disekolah maupun ditempat tinggal mereka, belum lagi sebagian besar dari mereka lebih banyak adalah anak-anak yang tinggal dipondok pesantren, sehingga waktu mereka terus terkontrol dengan belajar agama dan kegiatan-kegiatan yang positif. ${ }^{36}$

Setelah mendengar penjelasan dari beberapa informan yang telah diwawancara bahwasanya setiap peserta didik yang ikut serta dalam program tahfidz rata-rata memiliki kemampuan yang baik dalam membaca A I-Qur'an yang baik dan benar berdasarkan kaidah tajwid, serta memiliki hafalan ayat-ayat AI-Qur'an yang nantinya menjadi bekal dasar untuk memperdalam ilmu pengetahuan agama.

Dari paparan diatas dapat disimpulkan bahwa setiap siswa yang mengikuti atau menghafal Al-Qur'an memiliki kemampuan yang baik dari segi bacaan, penerapan hukum tajwid, serta memiliki hafalan AI-Qur'an yang berguna untuk berprestasi kedepannya.

\section{Perbandingan Hasil Belajar Siswa Penghafal Al-Qur'an dan bukan Penghafal}

Hasil belajar siswa penghafal Al-Qur'an di Madrasah Aliyah A l-Huda dalam aspek kognitif terkategori baik, hal ini dapat dilihat dari hasil belajar siswa di kelas yang menunjukkan bahwa siswa penghafal Al-Qur'an memiliki nilai dan intelegensi yang baik. Siswa penghafal A I-Qur'an di Madrasah Aliyah Al-Huda rata-rata tergolong siswa yang terkategori pintar dan mendapat nilai yang tinggi di kelasnya. Hal ini seperti yang di ungkapkan oleh kepala sekolah Madrasah Aliyah A I-Huda K ota Gorontalo yakni sebagai berikut.

36 Suharmin Alinti, Kepala Sekolah Madrasah Aliyah Al-Huda, wawancara, di Kota Gorontalo Tanggal 3 Juli 2019 
Menurut Suharmin Alinti untuk hasil belajar siswa penghafal Al-Qur'an dalam aspek kognitif atau kemampuan pengetahuannya sejauh ini di kelasnya rata-rata mempunyai prestasi yang baik. Rata-rata dari siswa penghafal Al-Qurean nilai mata pelajaranya tinggi-tinggi, dan itu tidak hanya mata pelajaran yang berbasis agama saja akan tetapi mata pelajaran yang umum juga seperti matematika, fisika, biologi, kimia, bahasa Indonesia, bahasa Inggris dan mata pelajaran umum lainnya rata-rata nilainya tinggi- tinggi. Ternyata hafalan AlQur'an memberikan dampak positif kepada siswa yang menjadikan siswa terbiasa untuk belajar dengan disiplin waktu sehingga nilai-nilai siswa dikelas ikut terdorong naik baik itu mata pelajaran umum terlebih mata pelajaran yang berbasis agama. 37

Hasil belajar siswa penghafal Al-Qur'an di Madrasah Aliyah A I-Huda K ota Gorontalo tergolong dalam kategori baik ini juga dibuktikan dengan rata-rata nilai raport siswa yang menunjukkan persentase nilai yang baik selama beberapa semester kebelakang sampai dengan sekarang.

\section{PENUTUP}

Strategi implementasi hafalan A I-Q ur' an terhadap hasil belajar peserta didik di madrasah aliyah Al-Huda Kota Gorontalo Berkontribusi positif pada perkembangan hasil belajar, hal ini disebabkan beberapa hal sebagai berikut.

1. Siswa lebih didorong untuk memantapkan hafalan ayat kemudian dievaluasi sejauh mana progres mereka, evaluasi sering dibuat dalam konsep teks mata pelajaran yang memuat ayat-ayat tentang fiqih, kisah peradaban manusia terdahulu, sikap dan perilaku baik dan tercela, dan keutamaan ibadah dll.

2. Tugas hafalan diluar sekolah, peserta didik selain diberikan tugas sekolah pada mata pelajaran baik agama maupun umum, peserta didik juga diberi target hafalan yang akan mereka persiapkan dan lancarkan ditempat tinggal mereka

37 Suharmin Alinti, Kepala Sekolah Madrasah Aliyah Al-Huda, wawancara, di Kota Gorontalo Tanggal 3 Juli 2019 
masing-masing untuk disetorkan pada esok hari, penanaman kebiasaan ini terus dilakukan agar waktu peserta didik dirumah tetap bersama kegiatan tahfidz, guru selalu menyampaikan pentingnya memelihara hafalan AI-Qur'an baik disekolah maupun diluar sekolah.

3. Setiap malam senin yayasan Al-Huda mengadakan pengajian umum tentang kitab tafsir, program ini juga berguna bagi peserta didik untuk menambah wawasan serta pengetahuan mereka tentang ayat-ayat Al-Qur'an yang telah mereka hapalkan.

\section{DAFTAR PUSTAKA}

A.M , Sardiman. 1992. Interaksi dan Motivasi Belajar M engajar Jakarta: Rajawali.

A bdurrahman A r R umi, Fahd. 1997. Ulumul Quràn Y ogyakarta: Titihan Ilahi Press.

A nshori, 2013. Ulumul Quran, Jakarta: Rajawali Press

A rikunto, Uharsimi. 2008. Dasar-dasar Evaluasi Pendidikan, J akarta: Bumi A ksara.

B uno, Hamzah dan Kuadrat, Masri. 2009. Mengelola K ecerdasan dalam B elajar, J akarta: B umi A ksara.

B. Uno, Hamzah. 2006. Perencanaan Pembelajaran, Jakarta: Bumi A ksara.

Bahri Djamarah, Syaiful. 1994. Prestasi Belajar dan Kompetensi Guru Surabaya: U saha Nasional.

Daradjat, Zakiah. 1996 Imu Pendidikan Islam, Jakarta: Bumi A ksara. 
Depag RI. 1987 al-Quràn dan Terjemah Jakarta: Serajaya Sentra.

Departemen Pendidikan dan K ebudayaan. Kamus Besar Bahasa Indonesia J akarta: B alai Pustaka, 2002.

Dimyati dan Mudjiono, Belajar dan Pembelajaran, Jakarta: Rineka Cipta, 2002

Djamarah, Syaiful Bahri. Psikologi Belajar, Jakarta : Rineka Citra, 2002

Efendi, Agus. Revolusi Kecerdasan Abad 21 Bandung: A lfabeta,2005

http://pksaceh.net/mengapa-kita-menghafal-tahfidzh-alqur\%E2\% 80\%99an/ Diakses 02 Desember 2017

Kamisa, Kamus L engkap Bahasa Indonesia, Surabaya: Kartika, 1997

Kamus Besar Bahasa Indonesia (http://kbbi.web.id/hafal diakses pada tanggal 16 oktober 2017 jam 08.45PM ).

M a'mur A smani, Jamal. 7 Tips A plikasi PAKEM, Jogjakarta: DIVA Press[Anggota [KAPI] 2011.

M onty P. Satiadarma \& Fidelis, M endidik Kecerdasan Jakarta: Bumi A ksara, 2009

Poerwadarminta, Kamus B esar B ahasa Indonesia, Jakarta: Duta Rakyat, 2002

Sa'dulloh , 9 Cara Praktis M enghafal A /-Qur'an Jakarta: Gema Insani, 2008

Sabri, Alisuf. Psikologi Pendidikan Jakarta: Pedoman IImu Jaya,2007 
Sardiman A.M, Interaksi dan Motivasi Belajar Mengajar, J akarta: Rajawali Pers, 2011

Shihab, M. Quraish Shihab, Wawasan al-qur'an, Bandung: Mizan, 1996

Shihab, M. Quraish. Sejarah dan U/um al-Qur"an, Jakarta: Pusataka Firdaus, 2008

Slameto, Belajar dan Faktor-Faktor yang Mempengaruhinya J akarta: Rineka Cipta, 2010

Soemanto, Wasty. Psikologi Pendidikan Landasan kerja pemimpin pendidikan J akarta: Rineka Cipta, 2006

Sudjana, Nana dan Rifa'l, A hmad. Media Pengajaran, B andung: Sinar A Igesindo, 2002

Syah, M uhibbin. Psikologi Pendidikan dengan pendekatan baru, B andung: Remaja Rosdakarya, 2010

Syah, M uhibbin. Psikologi Pendidikan dengan pendekatan baru, B andung: Remaja Rosdakarya, 2010

Syah, M uhibbin. Psikologi Pendidikan dengan pendekatan baru, B andung: Remaja Rosdakarya, 2010

Tim Prima Pena, Kamus Besar Bahasa Indonesia, J akarta: Gita M edia Press

Tohirin, Psikologi Pembelajaran Pendidikan Agama Islam, J akarta : Raja Grafindo Persada, 2006

Tu'u, Tulus Peran Disiplin pada Perilaku dan Prestasi Siswa, J akarta : Grasindo, 2004

W Hafidz, Ahsin. Bimbingan Praktis Menghafal al-Quràn J akarta: B umi aksara, 1994 
Jurnal Paedagogia Vol. 9 No. 1 Maret 2020

Warson, Munawwir, Ahmad Kamus Al-M unawwir, Y ogyakarta: Pustaka Progressif, 1997

Wijaya, Ahsin. Bimbingan Praktis Menghafal A/Qur'an.J akarta: A mzah. 2008.

Y usuf, Syamsu dan M, Nani. Perkembangan Peserta Didik Jakarta: Rajawali Pers, 2011

Zen, Muhaimin Tata Cara A tau Problematika Menghafal alQuràn J akarta:Pustaka A I-husna, 1985 